\title{
Comparative analysis of innovative activity of large business in Russia and the United States in terms of digitalization of the petrochemical industry
}

\author{
Irina $\mathrm{V}$. Bagaeva \\ Institute of Industrial Management, \\ Economics and Trade \\ Peter the Great Saint Petersburg Polytechnic \\ University \\ Saint Petersburg, Russia \\ irinabagaeva1@gmail.com
}

\author{
Galina N. Larionova \\ Nizhnekamsk Chemical Technological \\ Institute (branch of Kazan National Research \\ Technological University); \\ Nizhnekamsk, Russian Federation \\ galalar@yandex.ru
}

\author{
Yana R. Bagaeva \\ Nizhnekamsk Chemical Technological \\ Institute (branch of Kazan National Research \\ Technological University); \\ Nizhnekamsk, Russian Federation \\ ybagaeva1@gmail.com
}

\begin{abstract}
The relevance of the study is that the innovations in the oil and petrochemical industries are not only a way to increase production of raw materials and reduce losses when searching and developing new unconventional fields, but also a tool to increase the competitive advantages of vertically integrated oil companies that are increasingly interdisciplinary. Russian petrochemical manufacturers are seeking to bring advanced digital innovations to the local market - it is obvious that technology is the key to the high competitiveness in the global market. The Russian company Rosneft PJSC and the American ExxonMobil are no longer just oil-producing corporations. The scope of their activities includes such areas as deep processing of petroleum products, gas production, the production of synthetic and alternative fuels, clean energy and other areas that are characterized as the industry of the future. These areas of business require significant $R \& D$ investments, which in the future will provide companies with competitive advantages.
\end{abstract}

Keywords - innovation, digital economy, innovation activity, innovative behavior, research and development, digitalization of the petrochemical industry

\section{INTRODUCTION}

In the Russian economy, the raw materials sector, largely the oil industry is a budget-forming factor that makes a significant contribution to the socio-economic development of the state over a long time. Of course, the main factors for economic growth in the country are relatively high prices for oil and gas, which stimulates the high growth rates of their exports and foreign exchange earnings.

In 2012-2015 crude oil production increased in Russia, but growth rates were quite low. The reason for this slowdown in production is the deterioration of production conditions. Existing fields are gradually depleted, the water cut of wells increases, the content of impurities in the form of sand in the oil, etc. At the same time, oil experts say that new fields often have "the worst geological and geographic parameters" [2], oil production in such difficult areas will inevitably require an increase in capital, costs, operating and logistics costs.

Nowadays it is almost impossible to find an oil refining or petrochemical company that has not announced its plans to introduce digital solutions at its enterprises.
Today the Russian petrochemical industry is only taking the first steps in digitalization but has already achieved good results. First, petrochemical companies rely on investments in digital technology realizing the economic benefits of this decision. Secondly, in this industry a lot of attention is paid to cybersecurity issues. Thirdly, the adaptation of new technologies in existing enterprises takes into account social aspects.

To maintain a high level of competitive advantage requires a constant search for new innovative solutions on the open market, interaction with research centers, universities and sometimes even competitors. External R\&D can create more value and have a faster return since the product is already purchased at the finished stage, when it remains only to introduce it into a technological or economic process.

\section{LITERATURE REVIEW AND PROBLEM STATEMENT}

At present, the operating fields of the largest Russian companies are at the limit of exhaustion of their potential. To compensate the decline in oil production at existing fields, it is necessary to engage in the development of new fields, most of which are located in remote areas where there is practically no infrastructure (areas of the Far North and the Arctic shelf), which means additional investments in the development of these areas to create adequate working conditions and field exploitation. It is also necessary to solve the issue of introducing new technologies for the extraction of difficultly recoverable oil reserves in existing fields. This requires the attraction of investments and technologies that currently do not exist in Russia. To this end, the largest Russian companies are intensively searching for new technologies in the West. At the same time, in 2015, record oil production was recorded over the past decade, which is also confirmed by the data of annual reports of leading Russian petrochemical companies. In 2015, LUKOIL reached record-breaking oil production rates of more than 100 million tons, and Surgutneftegaz also increased this figure to 61.6 million tons. 
TABLE I. RUSSIA"S LARGEST OUL COMPANIES (2014)

\begin{tabular}{|l|l|lr|}
\hline Companies & $\begin{array}{l}\text { Crude Oil } \\
\text { Production }\end{array}$ & Capitalization \\
\hline «Rosneft» & 1,5 billion barrels & $\begin{array}{l}38,7 \text { billion } \\
\text { dollars }\end{array}$ \\
\hline «Lucoil» & 707 billion barrels & $\begin{array}{l}27,7 \\
\text { dollars }\end{array}$ \\
\hline «Gazprom-neft» & 482 billion barrels & $\begin{array}{l}10,5 \text { billion } \\
\text { dollars }\end{array}$ \\
\hline «Surgut-neftegaz » & 447 billion barrels & $\begin{array}{l}18,5 \text { billion } \\
\text { dollars }\end{array}$ \\
\hline
\end{tabular}

The largest oil producing companies in Russia are Rosneft (it became the leader in 2014 and retains its leading position to this day), Lukoil, Surgutneftegaz, Tatneft. Basic data on the companies are presented in table 1 .

In the Russian Federation, traditionally, the bulk of production comes from vertically integrated oil companies; however, in 2015, almost half of vertically integrated oil companies reduced the level of production when independent companies increased by almost $10 \%$. Also, one of the distinguishing features of the Russian petrochemical industry is the extensive development of the industry.

Experts point out a number of difficulties currently encountered in oil production in Russia. This is, above all, the deterioration of the overall technological potential of the oil production and refining complex. Capacities in large numbers reach a critical level of wear. The fixed assets in oil production are worn out by an average of $60 \%$ [3], their replacement and modernization requires the involvement of advanced technologies, including foreign ones. Another problem is the reduction in oil recovery factor (CIN). This trend is not new, but in recent years has increased significantly. CIN is one of the main indicators of the correct use of the resource base in oil production. During the period from 1960 to 2000, there was a decrease in this indicator from 0.45 to 0.29 [3]. Finally, many existing fields in Russia (if not speaking about promising offshore) are located in lowproductive formations with a specific weight of more than 35 $40 \%$.

This leads to the fact that the average values of the production of working wells are 10-11 tons / day. The share of hard-to-recover reserves in many Russian fields is more than $60 \%$ and sometimes it reaches $90 \%$ [3]. A competent innovation policy pursued both with the participation of the state and private business can help to eliminate such a situation. This is the development of new drilling technologies (horizontal drilling, drilling of lateral wells, hydraulic fracturing, etc.), more efficient extraction of residual reserves from existing wells, etc. In a word, the Russian Federation's oil and gas complex needs large-scale and expensive modernization: it is necessary to introduce new promising technologies including with the participation of industry, university and related science (specialized universities, RAS, research institutes at oil companies, etc.).

It should also be noted a certain negative impact of the sanctions imposed in 2014 against Russian oil companies.
Experts note that these sanctions include restricting the access of leading Russian oil and gas companies to the financial markets of EU countries, the USA, Canada, etc., and also (which is even more relevant for Russian companies) "restrictions on the supply of equipment and technologies to Russia, as well as the provision of services for the exploration and development of deep-sea and Arctic deposits and the extraction of shale oil" [4]. US sanctions apply to almost all the major oil and gas companies in Russia (Rosneft, Gazprom, Gazprom Neft, LUKOIL, Surgutneftegaz, NOVATEK, Transneft). A striking example of the negative effects of US sanctions policy is the actual winding down of a joint project for the development of the Russian Arctic shelf by the companies Rosneft and ExxonMobil. Moreover, if the United States extended sanctions to the entire oil and gas sector in Russia, the EU concentrated its sanctions mainly on the oil sector because of Europe's strong dependence on Russian gas imports, which is not the same for the United States.

Another negative factor for the Russian economy as a whole and investment in innovative projects within the oil industry is the downward trend in world oil prices. The fall in oil prices was affected by a slowdown in global economic growth, largely due to a slowdown in China's economy and a drop in its level of oil consumption.

As a summary, the following negative factors can be identified for the oil and gas complex of Russia in a given period of time:

- continuing US and EU sanctions against Russian oil companies, primarily in the area of a ban on the export of new technologies for underwater drilling on the Arctic shelf;

- dynamics of decline in oil prices, which among other things is dictated by the uncoordinated positions of the main oil-producing countries regarding oil production, in this regard, the factor of returning to the energy market of the Islamic Republic of Iran is particularly important;

- the trend of slowing growth of the world economy, in particular China - the main oil consumer.

TABLE II. THE LARGEST US OIL COMPANIES (as of 2015) [5]

\begin{tabular}{|c|c|c|}
\hline Companies & $\begin{array}{l}\text { Crude } \\
\text { Production }\end{array}$ & Capitalization \\
\hline «ExxonMobil» & $\begin{array}{l}1,5 \text { billion barrels } \\
\text { per year }\end{array}$ & $\begin{array}{ll}356 & \text { billion } \\
\text { dollars } & \end{array}$ \\
\hline «She & $\begin{array}{l}1,17 \text { billion } \\
\text { barrels per year }\end{array}$ & $\begin{array}{ll}197,4 & \text { billion } \\
\text { dollars } & \\
\end{array}$ \\
\hline «ConocoPhilips» & $\begin{array}{l}1,525 \text { billion } \\
\text { barrels per year }\end{array}$ & $\begin{array}{l}76,7 \\
\text { dollars }\end{array}$ \\
\hline $\begin{array}{l}\text { «OccidentalPetro- } \\
\text { leum» }\end{array}$ & $\begin{array}{l}0,23 \text { billion } \\
\text { barrels per year }\end{array}$ & $\begin{array}{l}0,45 \\
\text { dollars }\end{array}$ \\
\hline «EOG & $\begin{array}{l}0,209 \text { billion } \\
\text { barrels per year }\end{array}$ & $\begin{array}{l}0,3 \\
\text { dollars }\end{array}$ \\
\hline
\end{tabular}

In the US, the situation in the oil industry is as follows. We see a strong gap in the production and capitalization of companies in the United States, unlike in the Russian market. In fact, there are two clear leaders on the American market - 
powerful TNCs ExxonMobil and Shevron. As for the general trends of the American oil market, it was also subject to the volatility of oil prices, if in 2012 - 2013 discussions about the shale revolution were intensively conducted, then the fall in prices in 2015 (in some months to \$ $37-40$ per barrel) led to a sharp reduction in investment in this area. The latest information for the beginning of 2017 suggests that companies engaged in the production of shale oil in the United States were able to optimize costs and reduce production costs at which the comfortable price of a barrel would be $\$ 40$. This can lead to a significant drop in global oil prices and a fall in investment in innovative projects in Russian companies.

Another important factor that can influence the production volumes and, accordingly, the dynamics of oil prices is the decision on the issue of oil production in the Arctic regions of the United States. Shortly before the end of his presidential term, Barack Obama issued a decree freezing exploration and oil production in the Arctic regions of the United States. The new American president, Donald Trump, has actively advocated the lifting of this ban, but a number of procedures are required to repeal this decree, which means that this issue is still in a frozen state.

Thus, the following factors affect the US oil market: - $\quad$ general trend of decline in world oil prices, which makes shale oil production projects less profitable (this issue is resolved by a set of measures to reduce the cost of such production);

- $\quad$ the general trend of slowing global growth;

- $\quad$ the United States is gradually taking a course on import substitution in the field of oil supply, which in the future will mean a reduction in the volume of oil imports to this country and, in a separate perspective, their transformation into an exporting country.

The successful integration of the oil and gas complex of Russia into the global energy space that is being formed today will largely depend on the effectiveness of the implementation of innovative strategies that are being developed and implemented by Russian VIOCs. For example, the innovation strategy of the company Rosneft PJSC, adopted in 2011, includes 20 main areas of scientific and technological development, which are closely related to innovation. Among them are the following main areas:

- conducting large-scale geological exploration in order to detect and develop new fields and new strata on existing ones;

- drilling of new wells, including at existing fields;

- the use of innovative technologies to improve oil production (for example, increasing the flow rate at the ending wells);

- development of technologies for the extraction of oil and gas from alternative sources of hydrocarbons (viscous oil, gas hydrates, etc.);

- introduction of technologies for the use and production of alternative non-hydrocarbon raw materials;

- development of new promising fields on the shelf (the Arctic, the Black Sea, the Pacific Ocean);
- introduction of promising technologies "Upstream" and "Downstream";

- improvement and introduction of new oil refining technologies (including the production of fuel according to the Euro-5 standards and other products of more advanced oil refining;

- work on technologies of energy saving and environmental protection;

- development of alternative energy sources.

The program declared that the aggregate amount of funds to be allocated for these projects in 2011-2015 will be more than 50 billion rubles [6].

The program also highlighted the most important innovative programs of the company:

- project to increase the efficiency of development of deposits difficult for drilling and "hard-to-reach layers of the Bazhenov Formation";

- technology development project for more economically efficient completion of wells that are at the limit of their production rate;

- a number of projects for designing equipment and developing technologies for the development of oil and gas fields on the Arctic shelf (within this project cluster, the creation of the Arctic Research and Design Center for Offshore Development (ARC) in St. Petersburg was announced with the American company ExxonMobil however, in 2014 the project was frozen due to the sanctions policy (see above).

It was also announced about the implementation of several projects in the direction of corporate IT tools, technologies for the deep processing of petroleum products in order to reach the production of fuel according to Euro4 and Euro-5 standards.

Already in 2012, within the framework of this targeted program, Rosneft implemented 56 innovative projects, the company allocated two subsidiaries engaged in R \& D: Center for Research and Development, and RosneftSakhalin, OJSC (both in cooperation with ExxonMobil ").

It should be noted that the main areas of innovation activity of Rosneft are aimed at solving the problems of increasing the productivity of existing well clusters, at increasing their profitability, and also at finding new technologies for prospecting prospective oil fields on the shelf (Arctic, Sakhalin, Black Sea). Another important area of innovation is the modernization of the company's refineries to produce more modern types of motor fuels and oils according to Euro-4 and Euro-5 standards. In general, the innovation strategy of Rosneft can be called a strategy of catching-up innovation development (in comparison with the American company), which, however, was able to prove its effectiveness in the short and medium term.

We will analyze the innovation strategy of the American company. The company "ExxonMobil" in the innovation portfolio is much more diverse topics. So, back in 2011, the company's CEO Rex Tillerson outlined the 
following fundamental directions of innovation and research and development in the company [7]. Among them:

- intensification of upstream and downstream technologies, incl. horizontal drilling, hydraulic fracturing, etc.;

- development of synthetic / alternative fuels (based on methanol, hydrogen, ethanol, biofuels, mixed fuels);

- technology of natural gas production based on $\mathrm{CO} 2$ sub- surface pumping (CO2 CaptureforSubsurfaceInjection), at which the gas mixture consists of $65 \%$ $\mathrm{CO} 2,22 \%$ methane;

- carbon capture and storage technologies (CarbonCaptureandStorage (CCS);

- short-term and long-term fuel revolution, in which in the long-term it is planned to create a second generation of biofuels, as well as HCCL-based fuel cells. At the same time, the role of oil in a series of derivatives for alternative types of fuel along with natural gas, hydrogen, methanol, biofuels, etc., reduces to $10-15 \%$.

Here we should elaborate on the vision of the fuel revolution in the view of the management of the American company. According to them, over the next two decades, there will be a qualitative leap in the production of basic fuels for vehicles (the main consumer of crude oil today). From conventional gasoline fuels, there is currently a slow transition to hybrid vehicles, liquefied gas vehicles and diesel fuel. In the coming years, we can expect the emergence of transport operating on fundamentally new types of fuel methanol, ethanol, hydrogen and other chemicals that do not work on oil. At the same time, of course, there will be a long transitional period of coexistence of traditional and alternative types of transport, due to which global consumption of oil and oil products will not fall in the next couple of decades (but not much increase).

Based on the above prerequisites, the research centers of ExxonMobil (recall that the company cooperates with more than 80 leading US universities, such as Massachusetts University of Technology, Harvard, etc.), the company's management is already striving to conduct advanced research and development in the field of biofuels of the second generation of technologies for the production of dry fuel cells, hydrogen fuel, as well as carbon dioxide capture and processing and the production of new materials based on it whose oil used is currently the same (polymers, etc.).

Thus, it can be said that ExxonMobil invests precisely in technologies that reach a payback period at the turn of 20302040 [8], while, of course, research and development is carried out, aimed at commercialization in a much earlier period. At the same time, the company's profit rate is higher than that of its competitors.

The matrix of EM's innovative activity includes the following stages: concept development, technology development, commercialization. Here we see a typical example of an open model of innovation, when developed inside a company or acquired from outside know-how are not only used inside a company, but are actively brought to the external market, but at the same time serve to maintain the competitive advantages of this company.

In more details, this matrix is as follows: "Generating an idea — choosing and determining ways to implement economic and technological evaluation of an idea before starting development — development — validation pioneering implementation / testing - launching into commercial production — creating a brand" [8].

Based on the above, we can say that the innovative model of ExxonMobil is aimed at a more distant future compared to Rosneft, therefore, it requires more investment in research and development with a long payback period. At the same time, this model is open since it is expected, including the commercialization of the technology itself, when the first, most profitable cycle of innovation commercialization is completed.

Therefore, the model chosen by Rosneft has every reason in the short and medium term - oil exploration and production in difficult geographical areas of the Far North really requires large investments and complex technologies, but still it's worth looking at the actions of our overseas partners now they have mentally crossed the boundary of the hydrocarbon era and are preparing for a new technological leap.

TABLE III. ROSNEFT COSTS FOR INNOVATION IN 2012-2015

\begin{tabular}{|c|c|c|c|c|}
\hline Years & 2012 & 2013 & 2014 & 2015 \\
\hline $\begin{array}{l}\text { costs of } \\
\text { innovation }\end{array}$ & - & $\begin{array}{l}148,1 \\
\text { billion } \\
\text { rubles }\end{array}$ & $\begin{array}{l}170 \\
\text { billion } \\
\text { rubles }\end{array}$ & $\begin{array}{l}116,9 \\
\text { billion } \\
\text { rubles }\end{array}$ \\
\hline $\mathrm{R} \& \mathrm{D}$ costs & $\begin{array}{l}9,9 \\
\text { billion } \\
\text { rubles / } \\
335 \mathrm{mln} \\
\text { USD }\end{array}$ & $\begin{array}{l}23,2 \\
\text { billion } \\
\text { rubles / } \\
728 \mathrm{mln} \\
\text { USD }\end{array}$ & $\begin{array}{l}33,2 \\
\text { billion } \\
\text { rubles / } \\
864 \text { mln } \\
\text { USD }\end{array}$ & $\begin{array}{l}36 \\
\text { billion } \\
\text { rubles / } \\
590.5 \\
\text { mln } \\
\text { USD }\end{array}$ \\
\hline $\begin{array}{l}\text { Patent } \\
\text { applications } \\
\text { (pcs.) }\end{array}$ & 18 & 52 & 75 & 69 \\
\hline
\end{tabular}

At the same time, the company divides R\&D into two groups: involved and created by its own efforts.

Let's compare the cost of innovation activities of Rosneft with ExxonMobil. Immediately it is necessary to notice that in the company's annual reports there is no division into general innovation investments and the actual R\&D expenditures, so a comparison of the $R \& D$ expenditures of the two companies (in dollar terms) will be correct.

TABLE IV. EXXONMOBIL RESEARCH AND DEVELOPMENT (R \& D) COSTS IN 2012-2015 (IN MILLIONS OF US DOLLARS [9]

\begin{tabular}{|l|l|l|l|l|}
\hline Years & 2012 & 2013 & 2014 & 2015 \\
\hline R\&D costs & 1042 & 1044 & 971 & 1008 \\
\hline
\end{tabular}

From Tables 3.4, we see a pronounced upward trend in R\&D expenditures of the Rosneft company, which 
declined in 2015 in dollar terms primarily due to the abrupt devaluation of the national currency. Moreover, in 2014, the expenses of both companies on research and development were almost equal, which suggests that in recent years Rosneft has been investing more and more in this area, despite the decline in profits due to the depreciation of the ruble and some decrease in demand for Russia oil in overseas markets.

Moreover, in 2016, this dynamic led Rosneft to the top among the top 20 global oil companies in terms of the efficiency of investing in exploration and production (R\&D). The value of the specific efficiency of capital investments in research and development in 2016 is \$5 per b.e. The same indicator for ExxonMobil was 20.3 dollars. Thus, achievements in the innovation activities of Rosneft have led to an increase in the company's capitalization. At the same time, the activities of the Russian company are more and more like a closed model of innovation in a closed economy. By the exact expression of S.Y. Rumyantseva, "within a closed economy, one can consider the option of self- organizing according to the principle "innovations overcome depression" ... To win international competition, following the tenets of modern evolutionary economics, one should pursue an active industrial policy. At the same time, for the structures involved in the development of innovations, it is advisable to refer to the example of countries that have accumulated experience in using open innovation, the costs of which are substantially less than the costs of internal development"[10]. It remains our hope that the leadership of our country will adopt this strategy.

At the current stage of development in the Russian petrochemical industry solutions that would ensure return on capital investments in new plants are required, increase the reliability of existing enterprises, and also contribute to the efficiency and optimization of current activities both at the plant and at the corporate level. At the production level it is necessary to take measures to increase the reliability of assets, expand the capabilities of employees and increase efficiency of processes. And at the corporate level it is required to combine the assets, people and technological processes of various plants and aggregate data to optimize the valuechain and make quick decisions.

\section{SOLUTION TO THEPROBLEM}

In the world of innovation, traditionally there has been a division of companies into "leading" (leaders) and "led" (catching up). If we compare the two companies by countries, both companies can be recognized as leaders in innovation in their geographic regions (despite the transnational nature of both companies, the core of their business is still concentrated in Russia and the United States, respectively). However, in the context of the global oil and gas industry, it should be recognized that ExxonMobil is a leader, and Rosneft PJSC is catching up in a broad sense of innovation, if we take into account all directions. The American company makes large- scale innovative investments in the technologies of the future
- a battery for electric vehicles, alternative motor fuels, green energy, while Rosneft PJSC concentrates its innovative investments in oil production and refining. Admittedly, such a concentration of human and financial capital has borne fruit, the company has become the industry leader in Russia, and in terms of the efficiency of innovation in oil production has overtaken its ExxonMobil. This is due to the strategy of catching-up development of Russia, which still has a long way to restore high-tech and future industries.

The strategy of PJSC "NK" Rosneft"can be considered correct in the short and medium term, because it gave her the opportunity to become leaders in the industry and gain a strong position and secure for herself the innovative touched in the field of oil production and refining. On the other hand, the US sanctions policy against the Russian oil and gas complex actually buried promising innovation transfer projects (development of the Arctic shelf, the Black Sea shelf, etc.), which risks slowing down the trend of Rosneft in the direction of becoming a high-tech company.

In the long term, PJSC Rosneft needs to pay attention to new activities and technologies and, through benchmark analysis, form promising business areas in the future technologies, including using innovation transfer in areas not covered by the sanctions restrictions.

One of the key elements of Rosneft's strategy is to use breakthrough digital approaches.

Creating digital doubles is a digitalization trend that includes:

- $\quad$ big data technology and blockchain;

- $\quad$ predictive control;

- digital twins of enterprises;

- $\quad$ industrial Internet of things;

- $\quad$ self-learning systems based on artificial intelligence, etc.

Innovative Hybrid Twin model allows you to create a virtual clone of the object, its full digital copy taking into account all the technological features and simulate the optimal mode of the production process for all phases of operation.

The digital twin is a set of hybrid digital models covering the entire process chain no matter if it is exploration, mining or processing.

Technical processes in oil and gas sector are sensitive to many parameters, including the equipment operation, the correct functioning of the systems, the range of operating temperatures, pressure, etc.

Therefore, it is very important to automatically receive information about any deviations from normal operation.

Digital (hybrid) twins make it possible to predict the transition of equipment to a critical state and prevent it.

This in turn:

- significantly increases the efficiency of using technological equipment;

- multiple increases the safety of operation of hazardous 
- production facilities, allowing to predict the transition of equipment to a critical state.

Despite the fact that the innovation model of Rosneft PJSC is closed, this company has become a leader in its region. However, a comparative analysis of the performance of the two oil companies, PJSC NK Rosneft and ExxonMobil, says that the American company takes leading positions not only in the USA, but also in the world.

\section{DISCUSSION}

Thus, it can be stated that the innovation development strategies of the companies PJSC Rosneft and ExxonMobil reflect the general models of the development of the oil and gas sector in Russia and the United States, respectively. Both companies are specific benchmarks for analyzing the oil and gas sector in their countries. The open innovation strategy of major companies in the United States is expressed in ExxonMobil's strategy, which leads large-scale investments not only in oil production, but also in related industries that can be called future industries - unconventional fuel sources, biofuels, hydrogen fuel, etc [11]. The Russian company concentrates its investments mainly in oil production and refining, which allowed it to become a leader in the Russian market. It can be said that both strategies are justified in the context of the general trends and the potential of the oil and gas sector of the two countries, given the fact that the oil and gas industry of Russia demonstrates to a greater degree a strategy of catch-up development.

\section{ACKNOWLEDGMENT}

The reported study was funded by RSCF according to the research project № 19-18-00452.

\section{REFERENCES}

[1] Larionova G.N., Girfanova E.Y., Khismatullina A.M., Mulyukova R.R., Kiselev S.V. The prerequisites for the formation and development of the regional market of consulting services in the oilproducing regions of Russia //Mediterranean Journal of Social Sciences. 2015. - T. 6. - № 2 S3. - P. 169-175.

[2] Bobilev Y. Trends in the oil and gas sector // Economic issues. 2015. №6. P. 47 [Electronic resource] URL: http://www.iep.ru/

[3] Ovinnikova K.N. The current state of the oil and gas complex of Russia and its problems.// Bulletin of Siberian Science. - 2013. № 4 (10). -

P. 49 [Electronic resource] URL: http://www.lib.tpu.ru/

[4] Bobilev Y. Trends in the oil and gas sector // Russian economic development. 2014. №10. P. 41-43.

[5] Big Oil: Which Are The Top 10 Biggest Oil Companies?By Nick Cunningham $\quad \square \quad$ Nov 24, 2015URL: [Electronic resource] www.oilprice.com/Energy/Crude-Oil/Big-Oil-Which-Are-TheTop- 10-Biggest-Oil-Companies.html ; Top 10 us oil and gas companies based on market value URL: [Electronic resource] www.statista.com/statistics/241625/top-10-us-oil-and-gascompanies- based -on-market-value/

[6] Passport of the innovative development program of JSC "NK" Rosneft ", p. 2-3 [Electronic resource] URL: http//www.susu.ru/sites/default/files/book/, - P. 6. (accessed: 06.06.2019).

[7] ExxonMobil CEO Rex Tillerson surveys world energy, sees window of opportunity, much need for action [Electronic resource] URL: // http://www.economicclub.org/ (accessed: 06.06.2019)
[8] ExxonMobil 2017 Outlook for Energy: A View to 2040/ - p. 15 [Electronic resource] URL: http://www.exxonmobil.com.sg/APEnglish/Files/2015 (accessed: 06.07.2019)

[9] Summary annual report ExxonMobil 2015 [Electronic resource] URL: //http://aboutnaturalgas.com/en/company/multimedia/publications love rview (accessed: 26.06.2019)

[10] Rumyantseva S.Y. Innovation and economic behavior in modern models of economic growth and evolutionary economics// Bulletin of the South Ural State University. Series: Economics and Management.

- 2015. - №2 (9). - P. 34 [Electronic resource] URL://http://elibrary.ru/item.asp?id=23685765 (accessed: 06.06.2019)

[11] Ilin, I.V., Koposov, V.I., Levina, A.I. Model of asset portfolio improvement in structured investment products (2014) Life Science Journal, 11 (11), pp. 265-269. 